\title{
PREVENTION OF TAKING AND KILLING OF HOSTAGES: INTERNATIONAL LEGAL REGULATION
}

\author{
Oleksandr Sainchyn* \\ Oksana Kuchynska ** \\ Volodymyr Hryniuk ${ }^{* * *}$ \\ Yuliya Tsyganyuk ${ }^{* * *}$ \\ Maryna Hromova ${ }^{* * * * *}$
}

\begin{abstract}
In the 21st century, the threat of international terrorism has replaced the threat of "classic" military confrontations inherent in previous centuries. Despite the fact that terrorist attacks are usually aimed at achieving political goals, however, human lives often become a means of achieving such goals, which creates many challenges not only for world politics and global security but also for internal legal regulation. The issue of the legal definition of the taking and killing of hostages as the methods and types of committing terrorist acts is often fraught with significant difficulties. Using the method of comparative legal analysis, this study analyzes the legal norms of the Criminal Code of Ukraine, which provide for punishment for the murder of hostages, as well as some problems of interpreting these legal norms in the context of foreign experience. Having studied these circumstances, the authors emphasize the importance of differentiating the dispositive norms of the Criminal Code of Ukraine related to the murder of hostages. The study shows that the Crimi-
\end{abstract}

\footnotetext{
Oleksandr Sainchyn, Kherson State University, Odesa, Ukraine; sainchynole@ukr.net.

** Oksana Kuchynska, Institute of Law, Taras Shevchenko National University of Kyiv, Kyiv, Ukraine; okskuchynska@ukr.net.

**** Volodymyr Hryniuk, Institute of Law, Taras Shevchenko National University of Kyiv, Kyiv, Ukraine; volhryniuk@ukr.net.

${ }^{* * * * *}$ Yuliya Tsyganyuk, Khmelnytsky Institute of Interregional Academy of Personnel Management, Khmelnytsky, Ukraine; tsyganyukyu@yahoo.com.

${ }_{* * * * *}$ Maryna Hromova, Taras Shevchenko National University of Kyiv, Kyiv, Ukraine; marhromova@yahoo.com.
} 
nal Code of Ukraine contains identical legal norms providing for legal liability for the same criminal offense: the premeditated murder of a hostage and the taking of a hostage, which led to grave consequences. The study raises the question and encourages discussion as to whether the lack of direct intent in the killing of hostages is possible. Since scientific and theoretical developments in this direction and the practical testing of criminal law norms for the murder of a hostage and the taking of a hostage leave many open questions, criminal lawyers are given the opportunity for scientific and theoretical research.

KEYWORDS: premeditated murder, hostage, hostage-taking, grave consequence, liability, international legal regulations, the United Nations (UN), legal norm, killing of hostages, death of hostages.

\section{INTRODUCTION}

Counter-terrorism as an integral part of the concept of combating crime is an important element of ensuring the security of the world community. The transformation of terrorism from a local to a global phenomenon, the growing level of danger of terrorist threats in various regions of the world, the degree of their cruelty makes it necessary to develop and apply effective measures to counter such threats. International political and legal measures and initiatives to counter terrorism should ensure the full use of the capabilities of all branches of state power, society, bodies, forces, and means of ensuring security. Society should condemn and level the activities of social movements, individual subjects, states that share opinions on the possibility of solving controversial problems by terrorist methods. ${ }^{1}$

Despite its similarities, it is not difficult to distinguish between the terms "terror" and "terrorism". Both words are derived from the Latin word "terror" (fear, horror) and mean the use of violence for political and other purposes. Terror is usually associated with the activities of state power during certain periods of the existence of a state, but, in addition to state power, other forces are also able to instill terror. At the same time, terrorism (crimes of a terrorist nature), which occurs in one form or another, has all the characteristics of a crime. These crimes are united by one common term - terrorist crimes. Despite the existing differences, they represent a criminological homogeneous phenomenon. The commonality of the causal relationship determines the fundamental similarity of the cumulative criminological characteristics of these crimes, as well as the social, moral, and psychological characteristics of criminals. ${ }^{2}$

\footnotetext{
1 Vishnevetsky, K. V.: Terrorism. Victimological aspect, Theory and Practice of Social Development, 5(1) 2013, p. 333-340.

2 Varvin, S.: Violence or dialogue?: psychoanalytic insights on terror and terrorism, Routledge, 2018, $300 \mathrm{p}$.
} 
It should be noted that the issue of hostage-taking is usually considered in an inextricable relationship with the concept of terrorism since it basically involves the presentation of demands to the authorities, international organizations to coerce them to perform certain actions. At the same time, the factors of threats to public safety and intimidation of the population are predominant terrorism signs. Speaking about the issue of the hostage-taking outside of terrorist motives, it should be noted that the criminal legal definition of this kind of criminally punishable act is closely related to the illegal imprisonment or kidnapping of a person for mercenary motives. At the same time, despite the widespread opinion, terrorist attacks (from the point of view of criminal law the commission of terrorist acts) do not always involve taking hostages.

Modern research on the legal definition of hostage-taking in the context of terrorist threats is devoted to such issues as:

- hostage-taking by terrorists, human rights, and the protection of victims of terrorism in accordance with the European Convention on Human Rights; ${ }^{3}$

- the genesis of the norms on criminal liability for hostage-taking, ${ }^{4}$

- religious freedom and law from the standpoint of theistic and non-theistic approaches; ${ }^{5}$

- hostage-taking by militants in Western countries; ${ }^{6}$

- imitation of hostage-taking and its consequences, ${ }^{7}$

- the victimological aspect of terrorism. ${ }^{8}$

3 Galani, S.: Terrorist Hostage-taking and Human Rights: Protecting Victims of Terrorism under the European Convention on Human Rights, Human Rights Law Review, 19(1) 2019, p. 149-171.

4 Lopina, M. V.: Criminal law characteristics of hostage taking. Historical, philosophical, political and legal sciences, cultural studies and art history, Questions of theory and practice, 8(2) 2015, p. 123-126; Serebrennikova, A. V.; Lebedev, M. V.: Genesis of the norm on criminal liability for hostage taking in domestic law, Journal of Siberian Federal University. Humanities \& Social Sciences, 13(10) 2020, p. 1600-1609.

5 Menuge, A. J.: Religious liberty and the law: theistic and non-theistic perspectives, Routledge, 2017, $240 \mathrm{p}$.

6 Loertscher, S.; Milton, D.: Prisoners and politics: Western hostage taking by militant groups, Democracy and security, 14(1) 2018, p. 1-23.

7 Wojtasik, K.: Simulated hostage taking and its consequences. Orlando shooting case, Przegląd Bezpieczeństwa Wewnętrznego, 11(20) 2019, p. 368-381.

8 Vishnevetsky, K. V.: Terrorism. Victimological aspect, Theory and Practice of Social Development, 5(1) 2013, p. 333-340. 
The relevance of the article is determined primarily by the growth of terrorist threats around the world associated with:

- global migration and assimilation processes;

- adaptation policies pursued by different countries;

- differences in ethical and political views;

- the lack of international and national legal regulation of countering terrorist attacks;

- criminal legal definition for the taking and killing of hostages.

The study aims to assess the modern international legal regulation in the field of preventing the taking and killing of hostages and to outline the problems of modern criminal legislation of Ukraine on these issues in a comparative legal perspective from the standpoint of the criminal legal definition of a crime. At the same time, the study examines the question of whether the lack of direct intent in the killing of hostages is possible.

\section{MATERIALS AND METHODS}

This study is based on an analysis of:

1. international acts in the field of human rights protection:

- Universal Declaration of Human Rights;

- European Convention on Human Rights;

- Geneva Convention relative to the Protection of Civilian Persons in the Time of War of 1949.

2. international acts in the field of countering the taking of hostages:

- International Convention against the taking of hostages 1979.

3. national acts in the field of countering the taking of hostages:

- the United Kingdom Taking of Hostages Act 1982;

- the United States Code $§ 1203$.

4. national legislative acts in the field of criminal law:

- the Criminal Code of Ukraine;

- the Criminal Code of the French Republic.

Using the method of comparative legal analysis, the study analyzes legal norms of the Criminal Code of Ukraine, which provide for punishment for the murder of hostages, as well as some problems of interpreting these legal norms 
in the context of foreign experience. Initially, the study examines the genesis of international legislative regulation in the field of countering terrorism in connection with the issue of the taking and killing of hostages. Based on this context, the study examines the issue of the criminal legal definition of hostage-taking and killing from the position of Ukrainian legislation in comparison with legislative regulation of this issue in the countries of the Anglo-Saxon and Romano-Germanic legal systems.

\section{RESULTS}

In the context of continuous global processes, international cooperation changes its forms, approaches, and methods, following the direction of uniting all countries to discuss the most important global problems (maintaining international peace, promoting friendly relations and cooperation between states, protecting the environment, and preventing crime). In the context of international cooperation, the issue of preventing criminal offenses, such as the killing of hostages, is of vital importance.

Based on the provisions of Article 3 of the Universal Declaration of Human Rights, everyone has the right to life, liberty, and security of a person. In 1948, being a part of the USSR (the Union of Soviet Socialist Republics), Ukraine signed the aforementioned international legal act, thus proclaiming its commitment to the highest world values in the field of human rights protection. ${ }^{9}$ According to Article 9 of the Constitution of Ukraine, the Declaration is an integral part of the national legislation of Ukraine. In accordance with Article 3 of the Constitution of Ukraine, human life, health, honor, dignity, inviolability, and security are recognized as the highest social values. The main duty of the state is to assert and ensure human rights and freedoms. The issue of countering terrorism for Ukraine is of particular importance, as the state has faced in recent years an open manifestation of terrorist threats and has determined the fight against such threats as a national priority. ${ }^{10}$ Considering the issue of the criminal legal definition of terrorist threats in Ukraine, it is necessary to turn to the background and international context in the field of legal regulation of countering terrorism.

\footnotetext{
9 Mayers, D.: Humanity in 1948: The Genocide Convention and the Universal Declaration of Human Rights, Diplomacy \& Statecraft, 26(3) 2015, p. 446-472; Zivaty, V. G.: The UN in the foreign policy dialogue of civilizations West-East (From the Universal Declaration of Human Rights (1948) to progress in the XXI century), Scientific Bulletin of the Diplomatic Academy of Ukraine, 31(1) 2000, p. 67-72.

10 LAW OF UKRAINE On temporary measures for the period of the anti-terrorist operation [https://zakon.rada.gov.ua/laws/show/1669-18\#Text], accessed on 02/02/2021
} 
The first attempt to create an effective legal way to combat international terrorism, in particular with taking and killing of hostages, was made in $1937 .{ }^{11}$ The result of the three-year work of the expert commission at the Council of the League of Nations was the adoption of the Convention for the Prevention and Punishment of Terrorism. ${ }^{12}$ Unfortunately, due to the escalation of the political situation on the eve of World War II, the Convention never entered into force (only the Republic of India ratified it out of 23 member states). ${ }^{13}$

Despite the fact that the Convention was never ratified, it contained several provisions related to the issues raised in this study. For example, Article 2 of the Convention obliged each state party to comply with provisions on legal liability for the willful deprivation of liberty of heads of states, including a collegial body member performing the functions of a head of a state, state officials, and their family members. According to Article 1 of the Convention, these actions can be classified as terrorist acts and, therefore, hostage-taking.

In the second half of the twentieth century, the number of hostages among foreign diplomats, members of international organizations (in Central, Eastern, North America, Europe, and the Middle East), and public figures increased dramatically, becoming the preferred tactic of political terrorists (politically motivated or motivated by monetary gain). The most notable incidents in Europe were as follows:

- the capture of Israeli Olympic players in Munich in 1972;

- the hostage-taking of OPEC (the Organization of the Petroleum Exporting Countries) officials in Vienna in 1975;

- the kidnapping of Italian Prime Minister Aldo Moro in 1978;

- the hijacking of several planes involving the killing of hostages to obtain economic or political concessions (more than 20 incidents from the 1960s to the present).

A special place is occupied by the death of hostages during the terrorist attack on September 11, 2001, in the United States, which is considered one of the most brutal terrorist attacks in modern history.

\footnotetext{
11 Franck, T. M.; Lockwood, B. B.: Preliminary thoughts towards an international convention on terrorism, The American Journal of International Law, 68(1) 1974, p. 69-90.

12 Ibid.

13 Rupérez, J.: The United Nations in the fight against terrorism. United Nations Counter-Terrorism Committee Executive Directorate, 2006, p. 22-23 [https://www.un.org/sc/ctc/wp-content/uploads/2017/01/2006_01_26_cted_lecture.pdf], accessed on 02/02/2021
} 
As can be noted, the initiative related to the establishment of international cooperation in the fight against terrorism came from the countries most severely affected by terrorist attacks, while the very first treaties in force providing for measures to prevent hostage-taking were regional conventions. Thus, the Special Session of the General Assembly of the Organization of American States in 1971 led to the signing of the Convention to Prevent and Punish the Acts of Terrorism Taking the Form of Crimes Against Persons and Related Extortion That Are of International Significance. Article 2 of the Convention declares that kidnapping is a common crime of international significance. Consequently, under Article 3 of the Convention, persons accused or convicted of any of the offenses outlined in Article 2 of the Convention must be extradited in accordance with the provisions of existing extradition treaties between the parties or in accordance with the laws of a state party. Attention should also be paid to the fact that the Convention remains open for signature not only by the member states of the Organization of American States but also by any other state at the invitation of the General Assembly of the Organization of American States to sign it (Article 9 of the Convention). ${ }^{14}$

Hostage-taking is also considered a common crime of international concern in several other regional conventions. In particular, in accordance with Articles 1 and 2 of the 1977 European Convention on the Suppression of Terrorism, hostage-taking is considered a serious crime involving an infringement on life and physical integrity.

In 1976, under the auspices of the UN General Assembly, a special committee was established to develop a single international legal act on the fight against hostage-taking (the corresponding draft was submitted for consideration in 1977 at the initiative of Germany). In 1976, the UN General Assembly established a Special Committee for the Development of the International Convention against the Taking of Hostages (the bill was registered in 1977 at the initiative of Germany). The Convention against the Taking of Hostages was adopted by the General Assembly at its 34th session and opened for signature in 1979. This document provides information on a criminal offense of an international nature. This Convention is the first international instrument of its kind to consider the taking of hostages as a crime against international law. Article 1 of the Convention defines such crimes as the taking, detention, threat of murder, infliction of injury for the purpose of coercing a state, an international intergovernmental organization, an individual, a legal entity, or a group

14 OSCE: Status of the Universal Anti-Terrorism Conventions and Protocols as well as other International and Regional Legal Instruments related to Terrorism and Co-operation in Criminal Matters in the OSCE Area, OSCE, 2018 [https://www.osce.org/files/f/documents/5/8/17138_0.pdf], accessed on 02/02/2021 
of persons to commit or refrain from committing any action as a condition for hostages' release. Article 1 of the Convention also defines attempted crime or complicity in an offense. The guiding principle of the Convention is the inevitability of punishment of the perpetrators, regardless of where the crime was committed. Article 9 of the Convention provides that a request for the extradition of an alleged offender will not be granted if there are serious grounds for believing that the offender will be prosecuted for his/her political opinion, religion, race, nationality or ethnic origin, or on grounds that the offender may be subjected to degrading treatment or punishment.

Today's spread of terrorism is mainly associated with the exacerbation of existing conflicts and the emergence of new ones due to nationality, ethnic origin, or religious beliefs. Escalation of terrorist presence has highlighted the urgent need for a global response.

Within the framework of this study, it is of interest to consider the European Union (EU) experience concerning the legislative regulation of countering terrorism. According to EU law, terrorist crimes are actions:

- committed with the aim of seriously intimidating the population;

- aimed at unduly coercing a government or an international organization to commit or refrain from committing any action;

- aimed at significantly destabilizing or destroying the fundamental political, constitutional, economic, or social structures of a country or an international organization. ${ }^{15}$

Following a series of terrorist attacks in France and Belgium in 2015, the EU has made counterterrorism measures a priority since that year. While the primary responsibility for fighting crime and ensuring security rests with member states, terrorist attacks in recent years have shown that security is also a shared responsibility. The EU contributes to the protection of its citizens by helping its member states.

EU actions in this area include:

- expanding the exchange of information;

- strengthening of checks at external borders;

- preventing radicalization on the Internet;

15 European Council, Council of the European Union: EU's response to the terrorist threat [https://www.consilium.europa.eu/en/policies/fight-against-terrorism/], accessed on 02/02/2021; SUMMARY of Directive (EU) 2017/541 on combating terrorism. Fight against terrorism - definitions of terrorist crimes and support to victims [https://eur-lex.europa.eu/ legal-content/EN/TXT/?uri=LEGISSUM\%3A4322328], accessed on 02/02/2021 
- increasing the level of control over firearms;

- digitization of judicial cooperation;

- criminalization of terrorist crimes;

- taking measures related to the prevention of the financing of terrorism;

- harmonization of the use of air passenger data;

- strengthening cooperation with non-EU countries.

In 2015, EU leaders issued a joint statement to coordinate the efforts of the EU and its member states. This statement calls for concrete action, focusing on three areas of action:

- ensuring the safety of citizens;

- prevention of radicalization;

- protection of values;

- cooperation with international partners.

In November 2020, following terrorist attacks in France, Germany, and Austria, EU internal affairs ministers agreed to further strengthen their joint counter-terrorism efforts without compromising the EU's shared values of democracy, justice, and free speech. In December 2020, EU leaders reaffirmed their unity in the fight against radicalization, terrorism, and extremism. ${ }^{16}$

Turning to the issue of legislative regulation of Ukraine regarding legal responsibility for such offenses as the taking and killing of hostages with grave consequences, it should be noted that studies concerning the above offenses have been the subject of discussions between Ukrainian scientists for many years. ${ }^{17}$

It should be noted that the modern definition of a terrorist act in Ukrainian legislation is presented in the Criminal Code of Ukraine, adopted in 2001. The issue of adopting new legislative regulation in the criminal law sphere in Ukraine, simultaneously with the formation of a new current conceptual apparatus, has been discussed since the proclamation of the state's independence. Thus, the 1992 edition of the Criminal Code of Ukraine contained the wording "committing a terrorist act or sabotage" and provided for responsibility for it;

16 SUMMARY of Directive (EU) 2017/541 on combating terrorism. Fight against terrorism - definitions of terrorist crimes and support to victims [https://eur-lex.europa.eu/legal-content/ EN/TXT/?uri=LEGISSUM\%3A4322328], accessed on 02/02/2021

17 Sotula, O. S.: Premeditated murder of a hostage or abducted person: comparative aspects, Scientific Bulletin of Kherson State University. Series: Juridical Sciences, 3(3) 2015, p. 48-51. 
however, in particular, it did not even define a terrorist act.$^{18}$ For comparison, the Criminal Code of the Russian Soviet Federative Socialist Republic of 1960 in the first chapter ("State crimes") contained a rule of responsibility for a terrorist act. Chapter "Terrorist act" of Article 66 of the Criminal Code provided for responsibility for the murder of a government official (part 1), as well as for causing serious bodily harm to this person (part 2). The purpose of the terrorist act was to undermine or weaken Soviet power. ${ }^{19}$

As can be noted, in the situation with Ukrainian legislative regulation, there is the need to adopt norms that correspond to new circumstances and establish legal responsibility for threats of the extermination of people with the intention of achieving economic or political concessions.

The 2001 edition of the Criminal Code of Ukraine appeared before researchers in a completely new way. It contains clause 3 of part 2 of Art. 115 (premeditated murder of a hostage) and part 2 of Art. 147 (Hostage-taking of a minor; hostage-taking by an organized group; hostage-taking combined with the threat to kill people; hostage-taking that has caused grave consequences).

Clause 3 of part 2 of Art. 115 of the Criminal Code describes the murder of a hostage as the deliberate murder of a person who was kidnapped (openly, with or without the use of violence, by deception) to persuade a state, an international organization, a natural or legal person to commit or refrain from committing any action as a condition for the release of a hostage.

The envisaged criminal action can probably develop according to the following scenario. A kidnapper openly or secretly, with or without the use of violence, through deception abducts a person while making demands on state bodies, public organizations, individuals, or legal entities regarding the fulfillment or refraining from fulfilling specific obligations. At the same time, if certain requirements are met, the hostage, as one of the conditions for fulfilling the requirements put forward, will be released. In case of refusal of the indicated bodies to fulfill the conditions of the kidnapper, the latter kills the hostage. The sanction for this crime provides for imprisonment for a term of 10 to 15 years or life imprisonment.

Article 147 of the Criminal Code describes the taking of a hostage to induce hostage relatives, a state or other institution, a natural or an official person, to commit or refrain from committing any action as a condition for the release

18 Criminal Code of Ukraine of 1960 (former Criminal Code of USSR) [https://zakon.rada. gov.ua/laws/show/2001-05\#Text], accessed on 02/02/2021; Criminal Code of Ukraine [https:// zakon.rada.gov.ua/laws/show/2341-14\#Text], accessed on 02/02/2021

19 Makarov, G. S.: The history of the development of Soviet criminal legislation on responsibility for terrorism, Young Scientist, 11(1) 2015, p. 1078-1080. 
of the hostage. Part two of this article, along with the threat of killing people, provides for liability in cases where grave consequences have occurred. The legislator considers the death of one or several people to be the grave consequences of hostage-taking. ${ }^{20}$

Responsibility for this crime can be expressed in the form of imprisonment for a term of 7 to 15 years. Speaking about the disposition of the articles of the Criminal Code for the murder of a hostage and the taking of a hostage (when grave consequences have occurred), it should be noted that several questions arise in this regard.

It is incomprehensible that the Criminal Code requires two identical rules of law, providing for liability for virtually the same crime. For example, the premeditated murder of a hostage (Art. 115) is contained in Section 2 of the Special Part of the Criminal Code (Crimes against human life and health), and the hostage-taking (Art. 147) is placed by the legislator in Section 3 (Crimes against freedom, honor, and dignity of an individual). Thus, these Articles assume different criminal liability, whereas the consequences are the same - the death of a hostage. There is another issue. Namely, a criminal, killing a hostage (Art. 115), acts only with direct intent, and when taking a hostage (Art. 147), when grave consequences occur (the death of a hostage), the criminal may have both direct and indirect intent for the onset of these consequences. This may give the perpetrator more opportunities to defend his/her actions in court and prevent more severe punishment.

\section{DISCUSSION}

A significant factor indicating the increased danger of taking a hostage is that this type of criminal offense is closely related to such crimes as terrorism, the organization of illegal armed groups, kidnapping, as well as other acts that infringe on the constitutional order and state security. From the point of view of the government of a state, a strict position that excludes negotiations and harsh military intervention should send a clear signal to terrorists that they cannot "defeat" a sovereign state. However, from a victim's point of view, the government's political priorities during negotiations, the excessive lethal force used during the rescue operation, the lack of independent investigations into

20 Kopotun, I.: Scientific and practical commentary on the Criminal Code of Ukraine As of October 8, 2020 [https://cul.com.ua/preview/npk_kk_18.pdf], accessed on 02/02/2021; Tertishnik, V. M.: Scientific and practical commentary to the Criminal Procedure Code of Ukraine, ASK, Kyiv, 2017, 1056 p. 
the hostage killings, and the lack of compensation may well be viewed by them as violations of human rights. ${ }^{21}$

In this context, it is necessary to understand the difference between the unintentional killings of hostages by those holding them and as a result of the implementation of measures to release them. One of the relatively recent high-profile cases related to the killing of hostages was the case of the killing of the US and Italian hostages during the counter-terrorist operation against the extremist group Al-Qaeda as a result of an American drone strike in Pakistan. ${ }^{22}$ Although both cases concern the murder of hostages, however, in the described case, a different criminal legal definition of the murder of hostages is implied, not to mention the fact that such actions as the unintentional killing of hostages during military special operations can go beyond the plane of the criminal legal regulation. However, the last question is outside the scope of this study.

In the context of considering the aspect of the legal definition of the taking and killing of hostages in the context of the continental and Anglo-Saxon legal systems, one should refer to the examples of countries related to such legal systems. Thus, as an example, it would be interesting to consider Estonian legislation, which largely retained the features of Soviet criminal law, but adapted to the Acquis Communautaire.

Article 1241 of the Estonian Penal Code (Hostage-taking) provides that hostage-taking, combined with the threat of murder or bodily harm, to compel a state, an international organization, a natural or legal person or group of persons to commit or to refrain from committing any action as a condition for the release of the hostage - shall be punishable by imprisonment for a term of up to ten years. The same actions that have entailed grave consequences or were committed against a minor are punishable by imprisonment for a term of eight to fifteen years. ${ }^{23}$ It should be noted that the legislator in the text of the act does not define the concept of "grave consequences" from which it is assumed that the latter is an evaluative category for a court decision.

${ }_{21}$ Galani, S.: Terrorist Hostage-taking and Human Rights: Protecting Victims of Terrorism under the European Convention on Human Rights, Human Rights Law Review, 19(1) 2019, p. 149-171.

22 Baker, P.: Obama Apologizes After Drone Kills American and Italian Held by Al Qaeda, NYTimes, 2015 [https://www.nytimes.com/2015/04/24/world/asia/2-qaeda-hostages-wereaccidentally-killed-in-us-raid-white-house-says.html], accessed on 02/02/2021], accessed on $02 / 02 / 2021$

23 Criminal Code of Estonia [https://www.legislationline.org/documents/section/criminal-codes/country/33/Estonia/show], accessed on 02/02/2021 
The category of "grave consequences" as a qualifying feature also exists in the Russian Criminal Code, therefore a similar approach to the definition of grave consequences is typical for Russian criminal law. Modern Russian judicial and the investigative practice uses fairly stable criteria for categorizing certain grave consequences: they must be precisely established and proven within the framework of an investigated criminal case; a court's conviction must contain a reasoned recognition of certain damage as a grave consequence of the crime committed. In addition, a causal relationship must be established between hostage-taking and the resulting grave consequences. Grave consequences can be considered: the suicide of a person who has been taken hostage; the trauma of a victim during an unsuccessful attempt at release; intentional or reckless infliction of grievous harm to the hostage's health, causing him/her significant property damage, as well as other persons or organizations. ${ }^{24}$

Article 224-4 of the French Penal Code defines hostage-taking as the abduction, detention of a person for one of the following three purposes:

- to prepare, or to facilitate the commission of a crime or offense;

- to facilitate escape, or to ensure impunity for a criminal or an accomplice in a crime or offense;

- to achieve the fulfillment of a requirement or condition, in particular, the payment of a ransom.

Under current legislation, hostage-taking is a crime punishable by up to thirty years in prison.

It should be noted that the punishment can be reduced to ten years in prison if a hostage is released voluntarily until the seventh day from the date of his/ her abduction without following the order or condition of a hostage-taker. This reduction is possible except in cases where a victim has been subjected to particularly cruel treatment (the victim has received an injury or permanent disability caused as a result of acts of torture, conditions of detention, or deprivation of food or care) ${ }^{25}$

Thus, this norm of the French criminal law, in addition to those listed above, does not provide for the presence of additional qualifying signs (available in Ukrainian, Estonian, Russian legislation) related to the taking of hostages, their life, and health.

24 Lopina, M. V.: Criminal law characteristics of hostage taking. Historical, philosophical, political and legal sciences, cultural studies and art history, Questions of theory and practice, 8(2) 2015, p. 123-126.

25 Code penal [https://www.legifrance.gouv.fr/codes/section_lc/LEGITEXT000006070719/ LEGISCTA000006117597/\#LEGISCTA000006117597], accessed on 02/02/2021 
Legal regulation of the United Kingdom and the United States is the key example of the criminal law aspect of the taking, holding, and killing of hostages in Anglo-Saxon law. Federal legislation of the United States (18 U.S. Code $\S 1203$ - Hostage-taking), as can be noted, does not create preconditions for discrepancies concerning qualifying characteristics. Taking hostages in the United States is punishable by life imprisonment, and if someone dies while committing a crime - the death penalty. ${ }^{26}$

Hostage-taking law in the United Kingdom initially provides for life imprisonment for persons accused of hostage-taking. Today there is no punishment in the form of the death penalty in the UK. Under the Taking of Hostages Act 1982, taking a hostage is defined as a criminal offense. A hostage-taker, regardless of nationality, in the United Kingdom or elsewhere: detains any other person ("hostage") to coerce a state, international governmental organization or person to take or refrain from doing any act; threatens to kill, injure or continue to detain a hostage. A person guilty of an offense provided for by this Law shall be imprisoned for life. ${ }^{27}$

Speaking about the issue of the presence of cases of indirect intent in the killing of a hostage as a qualifying feature, it should be noted that this issue is very contradictory. In accordance with Russian jurisprudence, if a murder can be committed with both direct and indirect intent, then an attempted murder is possible only with direct intent. That is, when a perpetrator realized the social danger of his/her actions (inaction), foresaw the possibility or inevitability of the death of another person and wished for it to occur, but the death did not occur due to circumstances beyond his/her control (active resistance of a victim, interference of other persons, timely medical care of a victim, etc.). ${ }^{28}$ Based on this understanding, there can be no indirect intent in the killing of hostages.

Speaking about the disposition of Article 147 of the Criminal Code of Ukraine "Hostage-taking" in that part where it is about the onset of grave consequences, the commentary to this article suggests that the grave consequences of this crime are as follows:

- the infliction of grievous bodily harm, incl. entailing the death of a victim;

- the onset of large material damage;

26 U.S. Code. 18 U.S. Code $\S 1203$ - Hostage taking [https://www.law.cornell.edu/uscode/ text/18/1203], accessed on 02/02/2021

27 Taking of Hostages Act 1982 [https://www.legislation.gov.uk/ukpga/1982/28/body\#: :text $=1 \% 20$ Hostage $\% 2$ Dtaking.,U.K.\&text=(b)in $\% 20$ order $\% 20$ to $\% 20$ compel,commits $\% 20$ an\%20offence], accessed on 02/02/2021

28 Resolution of the Plenum of the Supreme Court of the Russian Federation dated January 27, 1999 No. 1 [https://www.vsrf.ru/documents/own/7794/], accessed on 02/02/2021 
- a significant aggravation of interstate or interethnic relations;

- a serious violation of the activities of institutions, organizations and enterprises, and the like.

Intentional murder of a victim under aggravating circumstances is defined by part 2 of Art. 147 and part 2 of Art. 115. ${ }^{29}$ As can be noted, the question of the role of direct or indirect intent in this situation remains open. The death of hostages due to the lack of water, food, or the proper treatment might not be a direct intent of hostage-takers (since it contradicts their goals), however, it should be understood that the hostage-takers could have foreseen such a scenario. ${ }^{30}$ In this situation, the question of the definition of such crimes (especially when it comes to the measure of criminal punishment), including the aggregate of crimes, is complicated precisely by the need to establish the presence or absence of direct intent. Thus, speaking about the Ukrainian criminal legislation, it can be noted that in this case, the legislator provided for the possible absence of direct intent on the part of the hostage-taker. This circumstance, in essence, causes the main contradictions, since it can lead to a mitigation of punishment for criminals, even though that a crime of hostage-taking in itself initially presupposes an increased public danger.

\section{CONCLUSIONS}

This study gives grounds to assert that at the international legal and national level, the issue of defining criteria for the taking and killing of hostages is still insufficiently researched. At the same time, the study gives reason to say that the Anglo-Saxon legal system countries (the UK and the USA) are less likely to show condescension to hostage-takers. The example of France suggests the opposite - France admits the presence of qualifying features that can mitigate the punishment for hostage-taking, taking into account aggravating circumstances. In general, it can be said that a similar approach is characteristic of Ukraine, Russia, and Estonia. The study gives grounds to assert that in a comparative perspective, Ukrainian legislation is very humane in matters relating to the punishment of hostage-takers, allowing some ambiguity in the wording that can become an obstacle to an objective crime qualification. This circumstance suggests that some norms of criminal law related to the issues of

29 Tertishnik, V. M.: Scientific and practical commentary to the Criminal Procedure Code of Ukraine, ASK, Kyiv, 2017, 1056 p.

30 Galani, S.: Terrorist Hostage-taking and Human Rights: Protecting Victims of Terrorism under the European Convention on Human Rights, Human Rights Law Review, 19(1) 2019, p. 149-171. 
a criminal legal definition of murder and hostage-taking also require scientific understanding and legal adjustment.

\section{LITERATURE}

1. Baker, P.: Obama Apologizes After Drone Kills American and Italian Held by Al Qaeda, NY Times, 2015 [https://www.nytimes.com/2015/04/24/world/asia/2qaeda-hostages-were-accidentally-killed-in-us-raid-white-house-says.html], accessed on 02/02/2021], accessed on 02/02/2021

2. Code penal [https://www.legifrance.gouv.fr/codes/section_lc/LEGITEXT00000 6070719/LEGISCTA000006117597/\#LEGISCTA000006117597], accessed on $02 / 02 / 2021$

3. Criminal Code of Estonia [https://www.legislationline.org/documents/section/ criminal-codes/country/33/Estonia/show], accessed on 02/02/2021

4. Criminal Code of Ukraine [https://zakon.rada.gov.ua/laws/show/2341-14\#Text], accessed on 02/02/2021

5. Criminal Code of Ukraine of 1960 (former Criminal Code of USSR) [https:// zakon.rada.gov.ua/laws/show/2001-05\#Text], accessed on 02/02/2021

6. European Council, Council of the European Union: EU's response to the terrorist threat [https://www.consilium.europa.eu/en/policies/fight-against-terrorism/], accessed on 02/02/2021

7. Franck, T. M.; Lockwood, B. B.: Preliminary thoughts towards an international convention on terrorism, The American Journal of International Law, 68(1) 1974, p. 69-90.

- DOI: https://doi.org/10.2307/2198803

8. Galani, S.: Terrorist Hostage-taking and Human Rights: Protecting Victims of Terrorism under the European Convention on Human Rights, Human Rights Law Review, 19(1) 2019, p. 149-171.

- DOI: https://doi.org/10.1093/hrlr/ngz002

9. Kopotun, I.: Scientific and practical commentary on the Criminal Code of Ukraine As of October 8, 2020 [https://cul.com.ua/preview/npk_kk_18.pdf], accessed on 02/02/2021

10. LAW OF UKRAINE On temporary measures for the period of the anti-terrorist operation [https://zakon.rada.gov.ua/laws/show/1669-18\#Text], accessed on $02 / 02 / 2021$

11. Loertscher, S.; Milton, D.: Prisoners and politics: Western hostage taking by militant groups, Democracy and security, 14(1) 2018, p. 1-23.

- DOI: https://doi.org/10.1080/17419166.2017.1380523 
12. Lopina, M. V.: Criminal law characteristics of hostage taking. Historical, philosophical, political and legal sciences, cultural studies and art history, Questions of theory and practice, 8(2) 2015, p. 123-126

13. Makarov, G. S.: The history of the development of Soviet criminal legislation on responsibility for terrorism, Young Scientist, 11(1) 2015, p. 1078-1080.

14. Mayers, D.: Humanity in 1948: The Genocide Convention and the Universal Declaration of Human Rights, Diplomacy \& Statecraft, 26(3) 2015, p. 446-472

- DOI: https://doi.org/10.1080/09592296.2015.1067522

15. Menuge, A. J.: Religious liberty and the law: theistic and non-theistic perspectives, Routledge, 2017, 240 p.

- DOI: https://doi.org/10.4324/9781315270661

16. OSCE: Status of the Universal Anti-Terrorism Conventions and Protocols as well as other International and Regional Legal Instruments related to Terrorism and Co-operation in Criminal Matters in the OSCE Area, OSCE, 2018 [https://www. osce.org/files/f/documents/5/8/17138_0.pdf], accessed on 02/02/2021

17. Resolution of the Plenum of the Supreme Court of the Russian Federation dated January 27, 1999 No. 1 [https://www.vsrf.ru/documents/own/7794/], accessed on $02 / 02 / 2021$

18. Rupérez, J.: The United Nations in the fight against terrorism. United Nations Counter-Terrorism Committee Executive Directorate, 2006, p. 22-23 [https:// www.un.org/sc/ctc/wp-content/uploads/2017/01/2006_01_26_cted_lecture.pdf], accessed on $02 / 02 / 2021$

19. Serebrennikova, A. V.; Lebedev, M. V.: Genesis of the norm on criminal liability for hostage taking in domestic law, Journal of Siberian Federal University. Humanities \& Social Sciences, 13(10) 2020, p. 1600-1609.

- DOI: https://doi.org/10.17516/997-1370-0666

20. Sotula, O. S.: Premeditated murder of a hostage or abducted person: comparative aspects, Scientific Bulletin of Kherson State University. Series: Juridical Sciences, 3(3) 2015, p. 48-51.

21. SUMMARY of Directive (EU) 2017/541 on combating terrorism. Fight against terrorism - definitions of terrorist crimes and support to victims [https://eur-lex. europa.eu/legal-content/EN/TXT/?uri=LEGISSUM\%3A4322328], accessed on $02 / 02 / 2021$

22. Taking of Hostages Act 1982 [https:/www.legislation.gov.uk/ukpga/1982/28/ body\#: :text=1\%20Hostage\%2Dtaking.,U.K.\&text=(b)in\%20order\%20to\%20 compel,commits\%20an\%20offence], accessed on 02/02/2021

23. Tertishnik, V. M.: Scientific and practical commentary to the Criminal Procedure Code of Ukraine, ASK, Kyiv, 2017, 1056 p.

24. U.S. Code. 18 U.S. Code $\S 1203$ - Hostage taking [https://www.law.cornell.edu/ uscode/text/18/1203], accessed on 02/02/2021 
25. Varvin, S.: Violence or dialogue?: psychoanalytic insights on terror and terrorism, Routledge, 2018, 300 p.

26. Vishnevetsky, K. V.: Terrorism. Victimological aspect, Theory and Practice of Social Development, 5(1) 2013, p. 333-340.

27. Wojtasik, K.: Simulated hostage taking and its consequences. Orlando shooting case, Przegląd Bezpieczeństwa Wewnętrznego, 11(20) 2019, p. 368-381.

28. Zivaty, V. G.: The UN in the foreign policy dialogue of civilizations West-East (From the Universal Declaration of Human Rights (1948) to progress in the XXI century), Scientific Bulletin of the Diplomatic Academy of Ukraine, 31(1) 2000, p. 67-72. 